\title{
Housing Affordability: Factors Influencing Housing in the Tamale Metropolis of Ghana
}

\author{
Yakubu A. Zakaria (Corresponding author) \\ Department of Governance and Development Management \\ Faculty of Planning and Land Management \\ University for Development Studies - Wa Campus, Ghana \\ C/o Zakaria A. Yakubu, Box TL 782, Tamale - Ghana \\ E-mail: zyakubu@uds.edu.gh \\ Elias Danyi Kuusaana \\ Department of Real Estate and Land Management \\ Faculty of Planning and Land Management \\ University for Development Studies - Wa Campus, Ghana \\ Box UPW 3, Wa - Ghana
}

Received: August 18, 2019 Accepted: September 10, 2020 Published: September 17, 2020

doi:10.5296/ijrd.v7i2.17540

URL: http://dx.doi.org/10.5296/ijrd.v7i2.7540

\begin{abstract}
Housing is considered a basic human need. Yet deficit housing supply plagues Ghana. Studies on housing concentrate mainly on offering accommodation that neglects the problem of its affordability. As a result, this study examines factors influencing housing affordability using the Tamale Metropolis as a case study. Using stratified random sampling methodology, 271 renters and homeowners was chosen. Data analysis utilized descriptive statistics. The study showed inflation, rapid urbanization, and building material costs were the dominant factors that influence housing affordability. Rent was also found to be relatively affordable for all categories of housing units. Furthermore, it emerged that the efforts of homeowners, the private sector developers, and the state in the provision of housing were insufficient in providing affordable housing. Consequently, tenants are forced to invest over longer years for constructing or buying a home. The private sector should use less-cost building materials in its projects to provide housing for rent and/or sale, and still present minimum quality standards. It will mean that construction costs will not be too high to justify a high rent once the building is completed. Rent will be on the low side when this happens so tenants can
\end{abstract}


afford to. Equally, it is precarious that the government joins forces with the private estate developers to put up flats at reasonable prices using cheap local building materials.

Keywords: Housing, affordability, housing demand, supply factors, Tamale Metropolis, Ghana

\section{Introduction}

Affordable housing is one of the most significant urban problems in the world's developing economies (Chowdhury, 2013). It comes in a range of shapes including compound houses; semi-detached; tents, kiosks, and containers; flats/apartments, and huts. Housing is a basic human right and a life-need (Awuvafoge, 2013; Bank of Ghana, 2007; Chowdhury, 2013; Fu, 2007; UN Habitat). It's also the single largest spending item in many households and individuals' budgets (Chowdhury, 2013; Litman, 2016). Household should therefore be able to afford a decent home without impairing its ability to spend on other necessities (Chowdhury, 2013).

Ghanaians are very preoccupied with owning their own home. The urban population of Ghana is very poorly built, relative to other countries in sub-Saharan Africa (Tipple, 2011). Single rooms occupy around 60 per cent of all urban households. This is because there was a housing deficit of 736,657 in Ghana as of 1970, which increased to 1,184,636 in 1984 to $1,526,275$ in 2000 . The supply deficit rose further in 2010 , to $1,600,000$. Approximately $35 \%$ of households can afford only GH12,000 or less (one room) and 85\% of all households can afford less than GH772,000 (Tipple, 2011).

The Tema Development Corporation (TDC), the State Housing Company, the National Shelter Strategy, the National Housing Strategy, the Home Finance Company (HFC), and the Ghana Vision 2020 (Awuvafoge, 2013; Boamah, 2014; Konadu-Agyemang, 2001; Nsiah-Gyabaah, 2009) were among some of the policies instituted to promote housing provision in Ghana. In addition, the formation of the Ghana Real Estate Developers Association (GREDA) in 1988 was timely, and its core intention was to promote the development of residential estates to increase the stock of housing units as a means of ensuring adequate provision of affordable housing for all socioeconomic groups (Awuvafoge, 2013; Tipple, 2011). Notwithstanding these major interventions in Ghana's housing sector, the situation of housing provision still leaves much to be desired.

Inadequate stock, overcrowding, housing decay and neighbourhood blight still characterise housing in Ghana (Boamah, 2014). The efforts have also been unsuccessful in providing middle- and low-income communities with affordable housing in the country (Awuvafoge, 2013; Boamah, 2010b, 2014; CHF International, 2004). The housing projects mostly benefited the upper class (Benjamin, 2007). Similarly, housing is characterized by high rental unit costs and high prices are for those in middle-class residential areas (Bank of Ghana, 2007). For example, most commercial properties in Ghana's major cities such as Accra, Tema, Sekondi-Takoradi and Kumasi are overpriced and largely dollar quoted. Beyond the dollarization of the property market in Ghana, many several other challenges make this effort to providing affordable housing ineffective. Equally important is that these invariably affect 
the living conditions of the people within the low socioeconomic group.

In the Metropolis of Tamale, the population in 2001 was 293,881, but decreased to 223,252 in 2010 (GSS, 2005b, 2014). This population reduction was due to the carving of the Tamale Metropolis from the Municipality of Sagnarigu. In 1984, the Tamale Metropolis was urbanized by 42 percent, but this decreased to 40.7 percent in 2000 and subsequently to 80.8 percent in 2010 (GSS, 2005b, 2014). By 2000, 65.5 percent of the Tamale Metropolis residents owned their homes, 27.3 percent leased while 6.7 percent lived in rent-free homes and the remaining 0.4 percent was perched (GSS, 2005b).

For 2010, 55 percent lived in their own dwellings while the rest were renting, perching or living in rent-free dwellings (GSS, 2014). This data tend to suggest that most people are not able to own their housing and are probably renting suggesting problems in housing affordability. Lower and middle-income earners are greatly disadvantaged in accessing affordable housing units, as housing prices far exceed their financial capacity (Yirenkyi, 2014). That makes it necessary to investigate how housing influences these categories factors in Ghana's Tamale Metropolis.

An examination of the literature on housing suggests that the concentration of most prior studies on housing were on its supply, demand, conditions and policies in the sector (Boamah, 2014; Tipple, 2011; Yakubu, Akaateba \& Akanbang, 2014) with little attention on factors influencing housing affordability. This creates a knowledge gap that requires an assessment. Although in the Tamale Metropolis some earlier studies (Boamah, 2010b; Biitir, 2009) have looked at affordability in housing, these studies have generally failed to consider factors influencing housing in the Tamale Metropolis of Ghana. These situations produce grey areas that require an empirical assessment. As such, it is worthy to investigate housing affordability in the Tamale Metropolis.

\section{Overview of Affordable Housing in Ghana}

In 2000 the population of Ghana was 18,912,079 but increased to 24,658,823 in 2010 (Ghana Statistical Service, 2005a, 2013). As of 2000, Ghana was further increased to about 51 per cent in 2010 by 44 per cent urbanized (GSS, 2005a, 2013). These population growth and urbanization trends statistics illustrate that the need for housing is on the rise. For the housing situation in Ghana, there was a housing demand of 1,678,296 (supply $=941,639$ ) by 1970, which in 1984 increased to 2,410,096 (supply $=1,226,360$ ) and in 2000 to 3,708,250 (supply $=2,181,975$ ) (Tipple, 2011). By 2010 the demand for housing continued to increase to $7,417,607$ with a supply of 5,817,607. This suggests that housing demand is steadily outweighing its supply (Boamah, 2010a; Mahama \& Antwi, 2006). This is because the housing industry in Ghana is at an elementary stage leading to high housing prices [i.e., for rent and/or purchase] (Ghana Bank, 2007).

To meet the housing needs of the various socio-economic classes, particularly the middle and low-income earners who do not have funds to meet their housing needs (Boamah, 2010b, 2014), it has resulted in the establishment of various steps. For individuals who largely provide housing, they do so at a slow pace as their finances are usually inadequate 
(Awuvafoge, 2013), as they rely mostly on their own resources with few of them going to mortgage (Ghana Bank, 2007).

Despite the efforts of both government and private organizations to provide affordable housing, these have been plagued by some challenges that limit their impact. Some of the challenges posed by the provision of affordable housing include high land construction costs, high labour costs, persistent land litigation, poor land tenure system, high borrowing costs, difficulty in obtaining funds and a shortage of building materials (Ghana Bank, 2007; Otiso, 2003; Tipple, 2011). These circumstances have tended to restrict housing supply in the Tamale Metropolis, which is one of Ghana's most populated metropolises (GSS, 2012).

\section{Factors Influencing Affordability of Housing}

Literature show that demand and supply related factors individually or jointly influence affordability of housing (Trimbath \& Montoya, 2002). The demand factors include rapid urbanization, household formation rates, household demographic characteristics, house-cost financing, and the country's macroeconomic conditions (Senayah, 2015). For the supply factors may include the availability and cost of land, labour, building materials, social infrastructure availability and housing finance. Housing affordability is shaped and determined by house prices, household income, household spending patterns and mortgage interest rates, according to Trimbath and Montoya (2002) and Norazmawati (2007) as cited in Ismail et al. (2015).

According to UN-Habitat (2011), the affordability of a house is mainly affected by capital variables (house purchase costs) and occupation variables (housekeeping costs). Thus, in the main, whether the household is a rented one or owner - occupied, the house's affordability is seen in two components: pre-acquisition affordability (capital variables) and post-acquisition affordability (occupation variables) (Senayah, 2015). The capital variables are seen in terms of the cost of property, services, building materials and labour, and the ability to fund the purchase, while the occupation variables are seen in terms of land lease and prices, service costs, and construction maintenance and financial inputs such as: loan repayment duration and interest rates, and household income minus non-housing expenditure (UN-Habitat, 2011).

A Bank of Ghana report (2007) found that 86 percent of respondents suggested that high cost of building raw materials was the most significant driving factor behind the rising prices of residential properties in the country on the causes of sustained increases in house prices. It is further noted that land costs have also been identified as the second largest factor behind the appreciable house price rises in Ghana, followed by labour costs, interest rates and obsolete technology.

Ismail et al. (2015) revealed that Bumiputera's major factors influencing housing affordability included banking restrictions, high patterns of expenditure, housing policies, and income. In addition, house prices are driven by economic growth, inflation, spreads across long-term maturities of short-term interest rates and bank loans between government bonds (Zainal, 2010). Higher lending rates, for example, would increase the cost of securing housing loans (Zainal, 2010). Macro- and micro-factors also influence the inability to own a house (Iman, 
2006). Factors which are considered a global macro factor or the overall economy to affect affordability of housing are economic, demographic, social and political (Iman, 2006). It is further noted that the micro factors consist of various aspects of financing, employment, income, expenditure on housing, house prices, monthly instalments, deposit or down payment, loan amount, loan term, interest rates and cost of financing. Assaf et al. (2010) found that some of the factors that significantly affect the cost of construction of affordable housing in Saudi Arabia include insufficient supply of labour, lack of planning, standard materials, length of the contract period, quality of design, material costs, changes in design, on-site conflicts, weak on-site financial management and previous experience. Moreover, questions like zoning, permits and densities affect housing affordability (Assaf et al., 2010).

\section{Materials and Methods}

Legislative Instrument 2068 (L.I. 2068) instituted the Tamale Metropolitan Assembly. It is currently one of the country's six Metropolitan Assemblies, and the only Metropolis in Ghana's three former northern regions. Two regions were carved out of the Northern Region in June 2018, namely: The Savannah Region and the Northeast Region.

Tamale is the metropolitan as well as the northern region's provincial capital. It is situated in the central part of the area and shares borders with the Municipality of Sagnarigu to the North-West, Mion District to the East and East Gonja to the South and Central Gonja to the South-West as shown in Figure 1. The Metropolis is the hub for local goods, particularly the agricultural and commercial goods from the other districts in the region and the southern part of Ghana, through this strategic location of Tamale. Several nearby West African countries such as Burkina Faso, Niger, Mali and Togo also stand to benefit in trade.

The Metropolis has an approximate total land area of 646.9sqkm (GSS, 2010). There are 116 communities in the Metropolis, 41 (35\%) of which are metropolitan, 15 (13\%) are peri-urban and $60(52 \%)$ are rural in nature. The rural parts of Tamale are the areas where land continues to predominate for agricultural activities and function as the Metropolis food basket.

During the rainy season, the Metropolis is filled with naturally grown, tall grasses used to make 'Zanamat' (GSS, 2002). After many people with different ethnic backgrounds started migrating from other areas to settle there, this area started experiencing high population growth, making it a cosmopolitan area (GSS, 2010). The Dagombas are the majority and other ethnic groups such as Gonjas, Mamprusis, Akan, Dagaabas and Frafras also reside in the Metropolis (GSS, 2010) among others. Other nationals from Africa and other countries around the world are also found in the Metropolis (GSS, 2010). 


\section{$\triangle$ Macrothink}

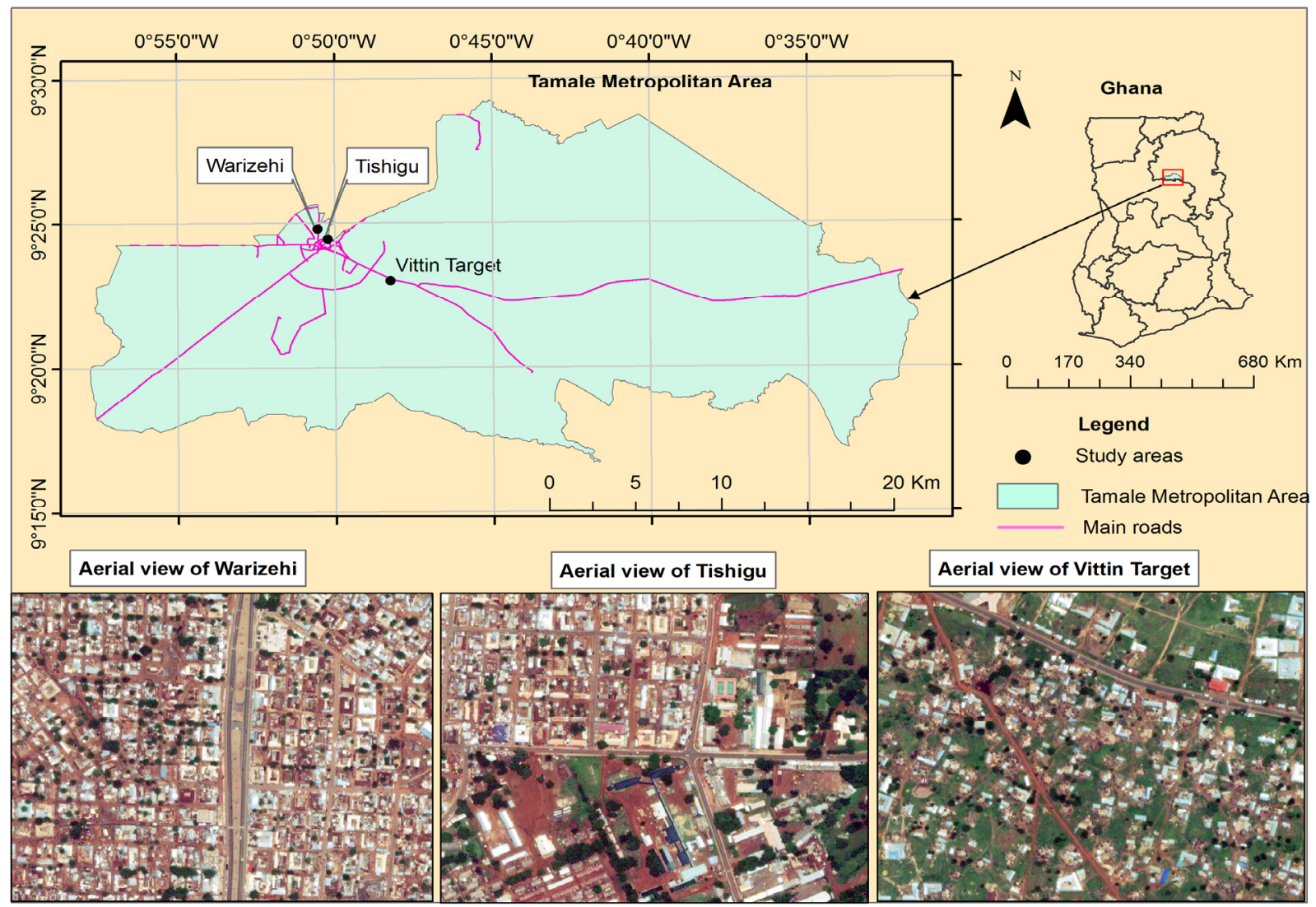

Figure 1. Map of Tamale Metro showing aerial view of the study areas

For this review the mixed methods analysis methodology has been adopted. Mixed methods investigation combines qualitative and quantitative research hypotheses (Creswell, 2003; Zohrabi, 2013). This research strategy allows many approaches to be used to answer research questions, rather than to limit the choices made by researchers (Johnson \& Onwuegbuzie, 2004). This method is deemed suitable for this study because it allows the simultaneous collection of both quantitative and qualitative data on this study. This helps to give a holistic picture of the study question. It also makes use of both quantitative and qualitative analytical approaches concurrently to help in providing clear explanation of issues. In terms of the study design, the case study design was employed.

The research proposed area is the Tamale Metropolis. The target population included renters who resided in the Metropolis of Tamale, officials of State Housing Company, Rent Control Unit and some Real Estate Developers who supplement the supply of housing units in Ghana. The reason was simply to profile their views with respect to their experiences in accessing housing and the professional experiences of the officials in the area of housing supply in Tamale and to see how those challenges they faced affect the affordability of the units they provide.

The analysis employed both probability and non- probability sampling techniques; this is due 
to the study's use of the mixed method approach. Simple and purposeful random sampling techniques were employed. Purpose sampling technique was used to gather data from officials with the required knowledge and information on the topic. Thus, the selection of these respondents was based on their expert knowledge on this study. Two (2) personnel from the Rent Control unit, 3 marketing officers from private real estate developers, and 3 officials from State Housing Company were purposively selected. Data from the respondents was triangulated to ensure the internal validity of the study.

Fisher, et al. (1998) formula for determining sample size was used to get a sample size of the household respondents. This formula is given as: Necessary sample size $=\left((\mathrm{z} \text {-score })^{2}\right.$ *standard deviation * $(1$-standard deviation $)) /(\text { margin of error })^{2} \mathrm{z}$-score $=1.645$; standard deviation $=0.5$; margin of error $=0.05$. Consequently, the sample size for the study was 271 renters. Tamale Metropolis was stratified based on low, middle, and high-income categorization areas. Warizehi, Tishigu, and Vittin- Target emerged as low, middle, and high-income zones respectively, according to the Ghana Statistical Service poverty mapping report 2015. The sample distribution for the three locations was proportionally based. For Warizehi the distribution was 129, for Tishigu 89 and for Vittin- Target 53.

Primary and secondary data were used in the study. Primary data were collected using interview guide. The primary data was collected through face-to-face interviews from the respondents in the study field. Secondary data were also collected to support the primary data from policy documents, journals, articles, and archival materials. This was needed to ensure triangulation of both the methodological and the source of data.

The design of instruments that the researchers employed in the collection of primary data was interview guide, an interview guide aided in the collection of data from renters. The justification for using this instrument was that not all the renters are literate and so the researcher and the enumerators had to administer the instruments personally. The interview guide covered the various arrangements put in for meeting housing need. The interview guide was structured into four sections with closed as well as open-ended questions. The instrument had instructions to guide the interviewer with respect to each section's expectations. Since the study methodology was the mixed method approach, it employed both quantitative and qualitative data analysis methods. The quantitative data was included in the Social Sciences Statistical Package and analysed. The analysis involved using descriptive statistics such as tables to understand demand-related factors that were endorsed as influencing affordability of housing by the renters from the Likert scale items. Using thematic analysis, it was analysed for the qualitative data. The thematic analysis helped segregate the factors into the factors in demand and supply. The analysis involved a detailed description of how each of the factors impacts the ability of individuals to rent and/or buy a house.

\section{Results and Discussion}

\subsection{Socio-Demographic Characteristics of Renters in Tamale Metropolis}

The study examined four background features of the respondents. These background characteristics included gender, age, location, and household size. Table 1 presents outcomes 
of respondents' background characteristics. The first feature of the context considered has been gender. 62.7 percent of the 271 respondents were males, while the remainder were females. That suggests most of the respondents were males. This is so because males who are normally household heads are culturally supposed to provide housing for their families in Tamale Metropolis. Another background feature examined was age of respondents. From Table 1, it is observed that of the 271 respondents, 50.6 percent of the respondents who constituted the majority were between the ages of 25 and 34 , while 8.1 percent of the respondents who fell between the ages of 15 and 24 were of the least category, the reason being that they are students in the areas. These findings indicate that most respondents are in the periods of productive age when they will work to earn an income and pay for their housing needs.

Furthermore, location of residences was considered. The results in Table 1 revealed that 47.6 percent of the respondents out of the 271 were from Warizehi, 32.8 percent from Tishigu and the rest $(19.6 \%)$ were from Vittin Target. This insinuates that most of the respondents of this study were from Warizehi. This result suggests that there are more renters in Warizehi compared to the other suburbs of the Tamale Metropolis. The last background characteristics looked at household size. Of the 271 respondents, the minimum number of people in a household was 3 whereas the maximum was 30. The median household population was 5 $($ Mean $=8.43$; Std. Deviation $=7.46$; Skewness $=1.19)$. This household size of 5 is less than the household size of 6.3 for the Tamale Metropolis discovered by the GSS (2014).

Table 1. Background features of respondents

\begin{tabular}{lcc}
\hline Variable & Number & Percent \\
\hline Sex & 170 & \\
Male & 101 & 62.7 \\
Female & $\mathbf{2 7 1}$ & 37.3 \\
Total & & $\mathbf{1 0 0}$ \\
Age & 22 & \\
$15-24$ & 137 & 8.1 \\
$25-34$ & 74 & 50.6 \\
$35-44$ & & 27.3 \\
\hline
\end{tabular}


45 and above

Total

\section{Location}

Warizehi

Tishigu

Source: Field Data (2020)

\subsection{Factors that Influence Affordability of Housing}

Housing is a basic human need, as such, it is crucial to determine the issues bordering on all groups of people's accesses to it. In this regard, this section focuses on rented type of housing, rental duration, rented house facilities and factors that determine affordability of housing. Details of these issues will be presented in the subsections that follow.

\subsubsection{Characteristics of Rental Housing in Tamale Metropolis}

The types of housing rented by respondents were considered and the results are presented in Table 2. The types of housing respondents rented were varied. They included detached house, semi-detached houses, flats/apartments, compound houses, huts and containers. The results show that major types of housing rented in a descending order were compound houses (67.5\%), flats/apartments $(11.1 \%)$ and detached house (10.7\%). This finding is consistent with that of GSS (2014) which also found that in the Tamale Metropolis, the major dwelling places constituted compound houses, flats/apartments, and detached houses, which is characteristic of urban areas. 
Table 2. Housing type rented

\begin{tabular}{lll}
\hline Housing Type & Number & Percent \\
\hline Detached house & 29 & 10.7 \\
Semi-detached houses & 21 & 7.7 \\
Flats/apartments & 30 & 11.1 \\
Compound houses & 183 & 67.5 \\
Huts & 6 & 2.2 \\
Container & 2 & 0.7 \\
Total & $\mathbf{2 7 1}$ & $\mathbf{1 0 0}$ \\
\hline
\end{tabular}

Source: Field Data (2020)

The compound house type dominated as the most rented housing type in all three study areas. This is because it is generally the dominant type of housing in the metropolis.

In the Tamale area, renting of flats/apartments and semi-detached houses were dependent on the location of the suburb. However, in both Tishigu and Vittin Target the next important types of housing rented after compound houses were flats/apartments while that of Warizehi were semi-detached houses, depicting variation in the housing types rented in table 3. 
Table 3. Housing type rented by residential areas

Housing Type

\begin{tabular}{llll} 
& Warizehi & Tishigu & Vittin Target \\
Detached house & $(7.0 \%)$ & $(14.6 \%)$ & $(13.2 \%)$ \\
Semi-detached houses & $(8.5 \%)$ & $(2.2 \%)$ & $(15.1 \%)$ \\
Flats/apartments & $(3.9 \%)$ & $(7.9 \%)$ & $(34.0 \%)$ \\
Compound houses & $(75.2 \%)$ & $(75.3 \%)$ & $(35.8 \%)$ \\
Huts & $(4.7 \%)$ & $(0 \%)$ & $(0 \%)$ \\
Container & $(0.8 \%)$ & $(0 \%)$ & $(0.9 \%)$ \\
Total & $(\mathbf{1 0 0} \%)$ & $\mathbf{( 1 0 0 \% )}$ & $\mathbf{( 1 0 0 \% )}$ \\
\hline
\end{tabular}

Source: Field Data (2020)

The number of rooms rented was also examined. This was critical in the determination of room occupancy level. In connection with the number of rooms rented, out of the 271 respondents, the minimum number of rooms rented was 1 while the maximum was 15 . The median number of rented rooms was 1 (Mean $=1.66$; Std. Deviation $=1.28$; Skewness $=$ 7.10). With a total household size of 2258 and 418 rooms rented, it gives room occupancy of 5.4 persons per room. This room occupancy is higher than the standard 1.5 persons-per-room (PPR) and/or 2 persons-per-bedroom (PPB) (Blake, Kellerson \& Simic, 2007). This shows that renters live in overcrowded accommodation in the Tamale Metropolis.

\subsubsection{Renting Duration}

The rental period was evaluated; the findings were first viewed from an aggregate point and subsequently disaggregated. From the general perspective, the results showed that the mean duration for respondents' renting was 2 years $($ Mean $=2.97$; Std. Deviation $=2.73$; Skewness $=2.91$ ). The minimum period for renting was 0.17 years with the maximum being 24 years. The median duration of period for renting of 2 years suggest that on the average; most of the respondents have not been renting for longer periods.

As regard to Warizehi, the results showed that the minimum duration for renting was 0.17 years while the maximum was 14 years with an associated median of 2 years (Mean $=2.78$; Std. Deviation $=2.40$; Skewness $=2.04$ ). In Tishigu, median duration for renting was 3 years (Mean 3.25; Std. Deviation $=2.89$; Skewness $=4.52$ ) with a maximum period of renting of 
24 years and a minimum of 0.80 years. Pertaining to Vittin Target, it had a minimum period for renting of 0.20 years whereas the maximum was 12 years with an associated median of 2 years $($ Mean $=2.96$; Std. Deviation $=3.21$; Skewness $=1.70)$. Using the median duration for renting, it is observed that Tishigu has a higher duration (Median $=3$ ) for renting compared with that of both Warizehi and Vittin Target which is 2 years. This accounted for the difference in the Tishegu region due to the 2015 Ghana Statistical Service Poverty Mapping Study that classified Tishegu as a middle-income city.

Table 4. Location by duration of renting

\begin{tabular}{llllllll}
\hline Location & Sample & Minimum & Maximum & Mean & $\begin{array}{c}\text { Standard } \\
\text { Deviation }\end{array}$ & Median & Skewness \\
\hline Warizehi & 129 & 0.17 & 14.00 & 2.78 & 2.40 & 2.00 & 2.04 \\
Tishigu & 89 & 0.80 & 24.00 & 3.25 & 2.89 & 3.00 & 4.52 \\
$\begin{array}{l}\text { Vittin } \\
\text { Target }\end{array}$ & 53 & 0.20 & 12 & 2.96 & 3.21 & 2.00 & 1.70 \\
\hline
\end{tabular}

Source: Field Data (2020)

Note: Rent duration is in years

\subsubsection{Facilities in Rented House}

The kind of housing that renters would go for would depend on the type of facilities that such an apartment has and the comfort and security that is obtainable. In this respect, this section focuses on looking at the specific facilities in rented houses, comfort derived from the facilities and cost associated with maintaining the facilities.

On the issue of the facilities available in rented houses the respondents enumerated a myriad of them. The results are presented in Table 5. The results indicate that of 76 multiple responses for those renting separate houses, toilet facilities $(30.3 \%)$, bathroom $(26.3 \%)$, electricity $(21.1 \%)$ and pipe borne water $(22.3 \%)$ were the facilities available in them. The results depict that most of the separate houses rented have toilet facilities with few having electricity. For the 55 multiple responses on facilities in rented semi-detached houses, respondents noted that they have toilet facilities (23.6\%), bathroom $(25.5 \%)$, electricity (21.8\%) and pipe borne water (29.1\%). With respect to the 113 multiple response for those renting flats/apartments, the results denotes that toilet facilities $(26.5 \%)$, bathroom $(26.5 \%)$, electricity (26.5\%) and pipe borne water (20.5\%) were some of the facilities in the accommodation. It is clear from the results that pipe borne water is the least facility in the flats/apartments. Equally, the results on 173 multiple responses on facilities in compound 
houses included toilet facilities (6.9\%), bathroom (26.5\%), electricity $(26.5 \%)$ and pipe borne water $(20.5 \%)$. The results indicate washrooms in the compound houses rented by the respondents are restricted. This might lead to open defecation due to the bad sanitation situation that could arise, which comes with its cholera health challenges.

Table 5. Housing type rented by facilities available

\begin{tabular}{lccccc}
\hline Housing Type & \multicolumn{2}{c}{ Facilities Available } & Total \\
\cline { 2 - 5 } & $\begin{array}{c}\text { Toilet } \\
\text { Facilities }\end{array}$ & Bathroom & Electricity & $\begin{array}{c}\text { Pipe Borne } \\
\text { Water }\end{array}$ \\
\hline Detached house & $(30.3 \%)$ & $(26.3 \%)$ & $(21.1 \%)$ & $(22.3 \%)$ & $\mathbf{( 1 0 0 \% )}$ \\
Semi-detached & $(23.6 \%)$ & $(25.5 \%)$ & $(21.8 \%)$ & $(29.1 \%)$ & $\mathbf{( 1 0 0 \% )}$ \\
Flats/apartment & $(26.5 \%)$ & $(26.5 \%)$ & $(26.5 \%)$ & $(20.5 \%)$ & $\mathbf{( 1 0 0 \% )}$ \\
Compound house & $(6.9 \%)$ & $(13.3 \%)$ & $(71.1 \%)$ & $(8.7 \%)$ & $\mathbf{( 1 0 0 \% )}$ \\
Hut & $(0 \%)$ & $(100 \%)$ & $(0 \%)$ & $(0 \%)$ & $\mathbf{( 1 0 0 \% )}$ \\
Container & $(0 \%)$ & $(0 \%)$ & $(100 \%)$ & $(0 \%)$ & $\mathbf{( 1 0 0 \% )}$ \\
\hline
\end{tabular}

Source: Field Data (2020)

*more than sample size due to multiple response

The cost of maintaining the facilities in a house is crucial because it has an impact on the money that will be available for meeting the basic needs of renters. In the light of this, it was deemed important to examine respondents' perception about the cost associated with servicing the facilities in their rented houses. It was considered from the general point and then disaggregated using housing type. Table 6 presents respondents' general views about the cost aligned with maintenance of facilities in the house. It is evident from Table 6 that out of the 271 respondents, 35.8 percent indicated that maintenance of the facilities in the rented houses was expensive whereas 64.2 percent of them held a contrary view. This means that though renting a house comes with extra cost of servicing the facilities in it, the renters are however able to cope. 


\section{Macrothink}

International Journal of Regional Development

ISSN 2373-9851 2020, Vol. 7, No. 2

Table 6 . Housing type rented by perception on cost of maintenance of facilities

\begin{tabular}{lccc}
\hline Housing Type & \multicolumn{2}{c}{ Maintenance of Facilities are Expensive } & \multirow{2}{*}{ Total } \\
\cline { 2 - 3 } & Yes & No & \\
\cline { 2 - 3 } Detached house & $(20.7 \%)$ & $(79.3 \%)$ & $\mathbf{( 1 0 0 \% )}$ \\
Semi-detached house & $(52.4 \%)$ & $(47.6 \%)$ & $\mathbf{( 1 0 0 \% )}$ \\
Flats/apartment & $(56.7 \%)$ & $(43.3 \%)$ & $\mathbf{( 1 0 0 \% )}$ \\
Compound house & $(31.7 \%)$ & $(68.3 \%)$ & $\mathbf{( 1 0 0 \% )}$ \\
Hut & $(66.7 \%)$ & $(33.3 \%)$ & $\mathbf{( 1 0 0 \% )}$ \\
Container & $(50.0 \%)$ & $(50.0 \%)$ & $\mathbf{( 1 0 0 \% )}$ \\
\hline
\end{tabular}

Source: Field Data (2020)

The perception of comfort obtained from the facilities in rented accommodation was disaggregated using housing type to determine renters' opinions on the issue. The results are presented in Table 7. It is observed from the results that majority of the respondents renting detached house $(79.3 \%)$, semi-detached house $(85.7 \%)$, flats/apartment $(86.7 \%)$, compound house $(78.1 \%)$, and hut (100.0\%) are of the view that the facilities in such accommodations make life comfortable for them. It is evident from the results that only few of the respondents indicated that the facilities availability does not make staying in them comfortable. 
Table 7. Housing type by perception on comfort derived from facilities in rented accommodation

\begin{tabular}{|c|c|c|c|}
\hline \multirow[t]{2}{*}{ Housing Type } & \multicolumn{2}{|c|}{$\begin{array}{l}\text { Comfort Derived from } \\
\text { Rented Accommodation }\end{array}$} & \multirow[t]{2}{*}{ Total } \\
\hline & Yes & No & \\
\hline Detached house & $(79.3 \%)$ & $(20.7 \%)$ & $(100 \%)$ \\
\hline Semi-detached house & $(85.7 \%)$ & $(14.3 \%)$ & $(100 \%)$ \\
\hline Flats/apartment & $(86.7 \%)$ & $(13.3 \%)$ & $(100 \%)$ \\
\hline Compound house & $(78.1 \%)$ & $(21.9 \%)$ & $(100 \%)$ \\
\hline Hut & $(100.0 \%)$ & $(0 \%)$ & $(100 \%)$ \\
\hline Container & $(50.0 \%)$ & $(50.0 \%)$ & $(100 \%)$ \\
\hline
\end{tabular}

Source: Field Data (2020)

\subsection{Factors Determining Housing Affordability}

As housing is a necessity that people cannot do without, the issues surrounding its access are becoming crucial. Access to the residential unit is therefore determined by its affordability. As a result, the factors affecting affordability of housing were deemed significant. Table 8 gives some of the factors that are likely to affect housing affordability.

Of the 16 factors rated, the remainder had more than 53 percent endorsement as factors influencing affordability of housing, except for deposit or down payment, which was considered as not affecting housing affordability. The demand factors included household formation rates, rapid urbanization, affecting house prices, household employment, and patterns of household spending, monthly instalments, mortgage interest, and inflation. 
Table 8 . Housing affordability factors

\begin{tabular}{|c|c|c|c|c|c|}
\hline No. & Item & SD/D & $\mathbf{U}$ & $\mathbf{A} / \mathbf{S A}$ & Total \\
\hline & Demand factors & & & & \\
\hline 1 & $\begin{array}{l}\text { Rate of household formation affects } \\
\text { affordability of housing }\end{array}$ & $(15.5)$ & $(18.5)$ & $(66.1)$ & (100) \\
\hline 2 & $\begin{array}{l}\text { Rapid urbanisation affects } \\
\text { affordability of housing }\end{array}$ & $(3.0)$ & $(13.7)$ & $(83.4)$ & (100) \\
\hline 3 & $\begin{array}{l}\text { House prices affects affordability of } \\
\text { housing }\end{array}$ & $(3.7)$ & $(9.2)$ & $(87.1)$ & (100) \\
\hline 4 & $\begin{array}{l}\text { Household income affects } \\
\text { affordability of housing }\end{array}$ & $(11.8)$ & $(20.3)$ & $(67.9)$ & (100) \\
\hline 5 & $\begin{array}{l}\text { Household expenditure patterns } \\
\text { affects affordability of housing }\end{array}$ & $(17.0)$ & $(28.0)$ & $(55.0)$ & (100) \\
\hline 6 & $\begin{array}{l}\text { Monthly instalments affect } \\
\text { affordability of housing }\end{array}$ & $(17.0)$ & $(25.1)$ & $(57.9)$ & (100) \\
\hline 7 & $\begin{array}{l}\text { Deposit or down payment affects } \\
\text { affordability of housing }\end{array}$ & $(17.3)$ & $(37.6)$ & $(45.0)$ & (100) \\
\hline 8 & $\begin{array}{l}\text { Mortgage interest rates affects } \\
\text { affordability of housing }\end{array}$ & $(20.7)$ & $(23.2)$ & $(56.1)$ & (100) \\
\hline 9 & $\begin{array}{l}\text { Inflation affects affordability of } \\
\text { housing }\end{array}$ & $(8.1)$ & (7.7) & $(84.1)$ & (100) \\
\hline & Supply factors & & & & \\
\hline 10 & $\begin{array}{l}\text { Availability and cost of land affects } \\
\text { affordability of housing }\end{array}$ & $(12.5)$ & (8.9) & $(78.6)$ & (100) \\
\hline 11 & $\begin{array}{l}\text { Cost of labour affects affordability of } \\
\text { housing }\end{array}$ & (12.9) & $(9.6)$ & $(77.5)$ & (100) \\
\hline 12 & $\begin{array}{l}\text { Cost of building materials affects } \\
\text { affordability of housing }\end{array}$ & $(9.2)$ & (8.9) & $(81.9)$ & (100) \\
\hline
\end{tabular}


13 Technology for building houses

$(61.3)$

(100) affects affordability of housing

14

Housing policies affects affordability of housing

15 Design of houses affects

16 Availability and cost of loans to finance housing construction affects affordability of housing

Source: Field Data (2020)

Note: $S D=$ Strongly Disagree; $D=$ Disagree; $U=$ Uncertain; $A=$ Agree; $S A=$ Strongly Agree

In an interview with the key informants, they also stated similar demand related factors. For example, a 56 years old landlord from Vittin Target (23 ${ }^{\text {rd }}$ January 2020) remarked:

Some of the factors that influence affordability of houses that we rent out include proximity to social services, nearness to the central business district, household expenditure patterns, mortgage interest and inflation.

This indicates that similar supply factors decide the willingness of people to buy or rent a residential accommodation in the Tamale metropolis. This confirms Senayah's (2015) findings that demand-related factors that determine housing prices include rapid urbanization, household formation rates, household demographic conditions, household financing, and macroeconomic conditions.

On the other hand, the supply-related factors that respondents agreed/strongly agreed on as factors influencing housing affordability were the availability and cost of land, labour costs, building materials costs, building housing technology, housing policies, housing design and availability and loan costs for financing housing construction. As some of the supply factors that affect the affordability of housing, the key informants listed cost of building materials, technology for building houses, housing policies, housing design, availability and cost of property, and labour costs. A key informant for instance, stated that:

I think that the ability of people to rent and/or buy a residential facility depends on the cost of labour, cost of building materials, technology for building houses, and availability and cost of loans. This influences the number of houses that can be supplied when required at reasonable prices to prospective tenants and/or buyers of houses (Key informant, 45 years old personnel from State Housing Company, 24 ${ }^{\text {th }}$ January 2020). 
This quotation implies that supply related factors greatly influences the affordability of housing provided for rent and/or for outright purchase. This concurs with the findings made by Montoya (2002), Norazmawati (2007) as cited in Ismail et al. (2015) and Senayah (2015).

With respect to the major factors affecting housing affordability in the Tamale Metropolis, this was done by using the percentages of respondents strongly agreed/agreed, as demonstrated in Table 8. Based on this, house prices, inflation, rapid urbanization, and building materials costs emerged as the major factors affecting affordability of housing. Except for labour costs, land supply and hypothetical interest raised by key informants, the rest were comparable to the major factors adduced by respondents as affecting housing affordability. The primary informants said these factors are important because they are the ones that often impact the costs involved in building a residential facility. That is, whether the cost involved will be high or low would depend on those factors.

\section{Conclusion and Policy Recommendation}

The affordability of housing in the Tamale metropolis is generally influenced by a range of factors. Demand factors influence household formation rates, rapid urbanization, house prices, household wages, and patterns of household spending, monthly payments, mortgage interest, and inflation. Whereas the supply factors involved land availability and cost, labour costs, building materials costs and building housing technology, housing policies, housing design, and loan availability and cost to finance housing construction.

Regarding rent, it was largely affordable regardless of the type of accommodation and location in the Metropolis of Tamale. Nevertheless, the measures enacted by homeowners, the private sector, and the state to tackle housing needs were woefully insufficient.

The study recommends the following to improve access and make housing more affordable. Firstly, involvement of the renters in the determination of the housing rent is crucial to ensuring that rent remains affordable to the tenants. Their involvement can be made possible when the rent control board makes it mandatory for the property owners to ensure that renters take part in decision-making about fixing of the rent they are to pay. Their contributions should also be binding on the property owners. This will ensure that the landlords/ladies do not arbitrary increase the rent to levels that the tenants cannot afford.

Also, rent control department must ensure that they monitor the rent set by the property owners. This is to make sure the rent charged is reasonable for the tenants being able to afford it. They will see to it that rent rises are justifiable. Where rent is found to be high, the rent control board may interfere without reasonable reason, and order certain property owners to pay the rent. To ensure obedience, anybody who flouts these directives will be heavily penalised.

Additionally, to make rent affordable, the private sector in its efforts to provide housing for rent and/sale should use building materials that cost less. This will ensure that when the building is completed the cost of construction will not be too high to warrant high rent. When this occurs, rent will be on the low side and renters will be able to afford. Finally, the 
government can be seen to be effectively discharging its responsibility of providing housing by developing an appropriate housing policy.

The State itself should collaborate with the private sector to provide affordable housing. This will increase housing supply thus reduce the price at which houses are sold or rented. This will be to the tenants' benefit, as housing will become even more affordable. The government could also ensure housing provision by lowering the taxes on building materials and lowering the costs associated with land leasing to reduce the costs associated with housing construction. With low construction costs involved, many of the tenants would now be able to build their own structures.

\section{References}

Acquaa-Harrison, R. (2004). Housing and urban development in Ghana with special reference to low-income housing. Retrieved from http://books.google.com/books?id=3N9d2k9T0AwC\&printsec=frontcover\&source=gbs_ge_s ummary_r\&cad $=0 \# \mathrm{v}=$ onepage $\& \mathrm{q} \& \mathrm{f}=$ false

Akuffo, A. (2006). HFC'S pioneering role and rational for conversion to full banking activities: sustainability of specialised lenders. The World Bank/International Finance Corporation (IFC), Housing Finance Conference, Washing DC, USA, 16-17 March.

Alonso, W. (1964). Location and land use. Massachusetts: Harvard University Press.

Asiah, O. (1999). The effect of the planning system on housing development: A study of developer's behaviour in Kuala Lumpur and Johor Bahru, Malaysia. Unpublished Doctor of Philosophy Thesis, University of Aberdeen.

Assaf, S. A., Bubshaitr, A. A., \& Al-Muwasheer, F. (2010). Factors affecting affordable housing cost in Saudi Arabia. International Journal of Housing Markets and Analysis, 3(4), $290-307$.

Arnstein, S. R. (1969). A ladder of citizen participation. JAIP, 35(4), 216-224.

Awuvafoge, S. A. (2013). Affordable housing in urban areas in Ghana: Issues and recommendations. Unpublished Master's Thesis, Ball State University, Muncie, Indiana.

Balchin, P. N, Bull, G. H., \& Kieve, J. L. (1995). Urban Land Economics and Public Policy (5th ed.). London: Macmillan Press Ltd.

Balchin, P. N., \& Kieve, J. L. (1982). Urban land economics (2nd ed.). London: Macmillan Press Ltd.

Bank of Ghana. (2007). The housing industry in Ghana: Prospects and challenges (policy Brief). Ghana: Research Department Bank of Ghana.

Baqutaya, S., Ariffin, A. S., \& Raji, F. (2016). Affordable housing policy: Issues and challenges among middle-income groups. International Journal of Social Science and Humanity, 6(6), 433-436. https://doi.org/10.7763/IJSSH.2016.V6.686 
Blair, J. P. (1995). Local economic development - Analysis and practice. California: SAGE Publications.

Blake, K. S., Kellerson, R. L., \& Simic, A. (2007). Measuring overcrowding in housing. Retrieved from https://www.huduser.gov/publications/pdf/measuring overcrowding _in_hsg.pdf

Benjamin, C. (2007). A brief history of housing in Ghana. Retrieved from West Africa Built Environment Research (WABER) Conference in Accra, Ghana at: British CouncilAccra-Ghana, Volume: Third (3rd) Edition.

Biitir, S. B. (2009). Provision of affordable housing for low income groups in tamale metropolitan area through self-help housing approach. Unpublished Master's Thesis, Kwame Nkrumah University of Science and Technology, Ghana.

Boamah, N. A. (2011). Housing finance in Ghana: Can community mortgage cooperatives provide a panacea? Ghana Journal of Development Studies, 7(1). https://doi.org/10.4314/gjds.v7i1.61399

Boamah, N. A. (2010a). Housing Finance in Ghana: Would Community Mortgage Cooperatives Provide a Panacea? Ghana Journal of Development Studies, 7(1). https://doi.org/10.4314/gjds.v7i1.61399

Boamah, N. A. (2010b). Housing affordability in Ghana: A focus on Kumasi and Tamale. Ethiopian Journal of Environmental Studies and Management, 3(3), 1-11. https://doi.org/10.4314/ejesm.v3i3.63958

Boamah, N. A. (2014). Housing policy in Ghana: The feasible paths. Ghana Journal of Development Studies, 11(1), 1-17. https://doi.org/10.4314/gjds.v11i1.1

Bond, P., \& Tait, A. (1997). The failure of housing policy in post-apartheid South Africa. Urban Forum, 8(1), 19-41. https://doi.org/10.1007/BF03036607

Bujang, A. A., Jiram, W. R. A., Zarin, H. A., \& Anuar, F. H. M. (2015). Measuring the Gen $\mathrm{Y}$ housing affordability problem. International Journal of Trade, Economics and Finance, 6(1), 22-26. https://doi.org/10.7763/IJTEF.2015.V6.435

Burgess, E. W. (1952). The growth of the city. In P. Parks, E. Burgess, \& C. McKenzie (Eds.), the city. Chicago: University of Chicago Press. https://doi.org/10.1007/978-0-387-73412-5_5

CHF International. (2004). Strategic assessment of the affordable housing sector in Ghana. USA: Cooperative Housing Foundation International.

Cohen, L., Manion, L., \& Morrison, K. (2007). Research methods in education (6th ed.). New York: Routledge.

Chowdhury, M. Z. S. (2013). The housing affordability problems of the middle-income groups in Dhaka: a policy environment analysis. (Unpublished Doctoral Thesis). University of Hong Kong, Pokfulam, Hong Kong SAR. http://dx.doi.org/10.5353/th_b5108652. 
Conger, R. D., Patterson, G.R., \&Ge, X. (1995). It takes two to replicate: A meditational model for the impact of parents' stress on adolescent adjustment. Child Development, 66(1), 80- 97.

Creswell, J. W. (2003). Research design: Qualitative, quantitative, and mixed methods approaches (2nd ed.). London: SAGE Publications.

Dolbeare, C. N. (n.d.). Housing affordability: Challenge and context. Retrieved from https://www.huduser.gov/publications/pdf/brd/15dolbeare.pdf

Dowall, D. E. (1989). Bangkok: A profile of an efficiently performing housing market. Urban Studies, 26, 327-339. https://doi.org/10.1080/00420988920080331

Dzangmah, H. T. (2012). Prospects and challenges of rental housing in Greater Accra Region. Unpublished Master's Thesis, Kwame Nkrumah University of Science and Technology, Ghana.

European Commission. (2011). Social climate report. Special Eurobarometer 370. Retrieved from https://ec.europa.eu/commfrontoffice/publicopinion/archives/ebs/ebs_370_en.pdf

European Mortgage Federation. (2010). HYPOSTAT 2010 a review of Europe's mortgage and housing markets. Unpublished Manuscript. Retrieved from file://C:/Users/louis\%20zaukuu/Downloads/HYPOSTAT\%202010.pdf

Erguden, S. (2001). Low-cost housing: policies and constraints in developing countries. Paper presented for International Conference on Spatial Information for Sustainable Development, 2-5 October 2001, Nairobi. Retrieved from https://www.fig.net/resources/proceedings/2001/nairobi/erguden-CMTS1-1.pdf

Gan, Q., \& Hill, R.H. (2008). Measuring housing affordability: Looking beyond the median (Discussion Papers 2008-09). Australia: The University of New South Wales. Retrieved from https://core.ac.uk/download/pdf/6758895.pdf

Ghana Statistical Service. (2002). 2000 Population and Housing Census of Ghana. Accra: GSS.

Ghana Statistical Service [GSS]. (2012). 2010 population and housing census: Summary of results. Retrieved from http://www.statsghana.gov.gh/docfiles/2010phc/Census2010_Summary_report_of_final_resu lts.pdf

Ghana Statistical Service [GSS]. (2005a). Population data analysis report-socioeconomic and demography trends analysis (Volume 1). Accra: Ghana Statistical Service.

Ghana Statistical Service. (2005b). 2000 population and housing census: analysis of district data and implications for planning northern region. Accra: Ghana Statistical Service.

Ghana Statistical Service [GSS]. (2013). 2010 population and housing census: Demographic, social, economic and housing characteristics. Accra: Ghana Statistical Service. 
Ghana Statistical Service. (2014). 2010 population and housing census report: District analytical report-Tamale Metropolis. Accra: Ghana Statistical Service.

Goh.J. (2012). Property prices increase at slower pace. The EDGE. Retrieved from http://www.theedgemalaysia.com/in-the-financial-daily/215199-property-prices-increase-atslower-pace.html

Griffee, D. T. (2012). An introduction to second language research methods: Design and data (1st ed.). United States of America: TESL-EJ Publications. Retrieved from http://www.tesl-ej.org/pdf/ej60/sl_research_methods.pdf

Iman, A.H.M. (2006). Basic aspects of property market research. Malaysia: Universiti Teknologi Malaysia.

Ismail, A., Bujang, A. A., Jiram, W. R. A., Zarin, H. A., \& Jaafar, M. N. (2015). Factor Affecting the Housing Financing of Bumiputera in Iskandar Malaysia. Journal of Economics, Business and Management, 3(11), 1031-1036. DOI: 10.7763/JOEBM. 2015.V3.329

Johnson, R. B., \& Onwuegbuzie, A. J. (2004). Mixed methods research: A research paradigm whose time has come. Educational Researcher, 33(7), 14-26. https://doi.org/10.3102\%2F0013189X033007014

Jordaan, A. C., Drost, B. E., \& Makgata, M. A. (2004). Land value as a function of distance from the CBD: The case of the eastern suburbs of Pretoria. SAJEMS NS, 7(3), 532-541. https://doi.org/10.4102/sajems.v7i3.1363

Konadu-Agyeman, K. (2001). The political economy of housing and urban development in Africa: Ghana's experience from colonial times to 1998. Westport: Praeger Publishers. Retrieved from https://trove.nla.gov.au/work/7206378

Krieger, J., \& Higgins, D.L. (2002). Housing and health: Time again for public health action. Journal of Information, 92(5). https://dx.doi.org/10.2105\%2Fajph.92.5.758

Kumar, R. (2011). Research methodology: A step-by-step guide for beginners. New Delhi, India: SAGE Publications.

Lee, M. (2016). Getting serious about affordable housing: Towards a plan for metro Vancouver. Vancouver: Canadian Centre for Policy Alternatives. Retrieved from https://www.policyalternatives.ca/sites/default/files/uploads/publications/BC\%20Office/2016 /05/CCPA-BC-Affordable-Housing.pdf

Lerman, D. L., \& Reeder, W. J. (1987). The affordability of adequate housing. American Real Estate and Urban Economics Association Journal, 15(4), 389-404. https://doi.org/10.1111/1540-6229.00439

Linneman, P. D., \&. Megbolugbe, I. F. (1992). Housing affordability: myth or reality? Urban Studies, 29(3-4): 369-392. https://doi.org/10.1080\%2F00420989220080491 
Litman, T. (2016). Affordable-accessible housing in a dynamic city: Why and how to increase affordable housing in accessible neighbourhoods. Retrieved from https://www.vtpi.org/aff_acc_hou.pdf

Liu, M. (2010). Housing affordability problem in Shanghai. Retrieved from https://www.kth.se/polopoly_fs/1.127769.1550157590!/Menu/general/column-content/attach ment/43.pdf

Mahama, C., \& Antwi, A. (2006). Land and property markets in Ghana (Discussion Paper World Urban $\quad$ Forum III). Retrieved from http://www.urbanlandmark.org.za/downloads/Land_property_market-ghana.pdf

McKinsey Global Institute. (2014). A blueprint for addressing the global affordable housing challenge.

Retrieved from https://www.mckinsey.com/ /media/McKinsey/Featured\%20Insights/Urbanization/Tackling $\% 20$ the $\% 20$ worlds $\% 20$ affordable $\% 20$ housing\%20challenge/MGI_Affordable_housing_Exec utive\%20summary_October\%202014.pdf

Morrow, M. J. (2001). Affordable housing policy: Integration of land use tools and the role of state growth management. Unpublished Master's Thesis, Virginia Polytechnic Institute and State University.

Mills, E. S., \& Hamilton, B. W. (1994). Urban Economics (5th ed.). HarperCollins: New York.

Neuman, W. L. (2011). Social research methods: Qualitative and quantitative approaches (3rd ed.). Boston: Pearson.

Norris, M., \& Shiels, P. (2004). Regular national report on housing developments in European countries. Ireland: Department of the Environment, Heritage and Local Government. Retrieved from https:/www.housing.gov.ie/sites/default/files/migrated-files/en/Publications/Developmentan dHousing/Housing/FileDownLoad,2453,en.pdf

Nsiah-Gyabaah, K. (2009). Urban Housing Challenge and Prospects for Meeting the Housing Needs of the Urban Poor in Ghana. Proceedings at the 2009 National Housing Conference. Accra, Ghana. https://doi.org/10.4236/epe.2020.126019

Ogu, V. I., \& Ogbuozobe, J. E. (2001). Housing policy in Nigeria: Towards enablement of private housing development. Habitat International, 25(4), 473-492. Retrieved from https://doi.org/10.1016/S0197-3975(01)00018-2

Otiso, K. M. (2003). State, voluntary, and private sector partnerships for slum upgrading and basic service delivery in Nairobi City, Kenya. Cities, 20(4), 221-229. https://doi.org/10.1016/S0264-2751(03)00035-0

Ong, T. S. (2013). Factors affecting the price of housing in Malaysia. Journal of Emerging Issues in Economics, Finance and Banking (JEIEFB), 1(5), 414-429. Retrieved from 
http://globalbizresearch.org/economics/images/files/73848_JEIEJB_\%20Tze\%20San\%20On g.pdf

Oxley, M. (2004). Economics, planning and housing. England: Palgrave McMillan.

Paris, C. (2007). International perspectives on planning and affordable housing. Housing Studies, 22(1), 1-9. https://doi.org/10.1080/02673030601024531

Peter, K. (2009). Understanding housing finance, meeting needs, and making choices. Unpublished Manuscript.

Pittini, A. (2012). Housing affordability in the EU current situation and recent trends (CECODHAS Housing Europe's Observatory Research Briefing No. 1). Brussels, Belgium: CECODHAS Housing Europe Observatory Housing Europe Centre. Retrieved from https://doi.org/10.13128/Techne-11486

Sarantakos, S. (2005). Social research (3rd ed.). New York: Palgrave Macmillan.

Satsangi, S., Higgins, M., Pawson, H., Rosenburg, L., Hague, C., Bramley, G., \& Storey, C. (2001). Factors affecting land supply for affordable housing in rural areas. Edinburgh: Central Research Unit. Retrieved from https://www2.gov.scot/resource/doc/156515/0042026.pdf

Sengupta, U. (2006). Government intervention and public-private partnerships in housing delivery in Kolkata. Habitat International, 30(3), 448-461. Retrieved from https://doi.org/10.1016/j.habitatint.2004.12.002

Seraj, T. M., \& Afrin, S. (2003). Solving housing problem through private sector real estate development in Dhaka. Dhaka: Centre for Urban Studies (CUS) and Bangladesh Institute of Planners (BIP). https://doi.org/10.1177\%2F0975425320938581

Sivam, A. (2002). Constraints affecting the efficiency of the urban residential land market in developing countries: a case study of India. Habitat International, 26, 523-537. https://doi.org/10.1016/S0197-3975(02)00025-5

Senayah, E. A. K. (2015). Housing affordability in Kumasi: Towards improving housing delivery in the city. Unpublished Master's Thesis, Kwame Nkrumah University of Science and Technology, Ghana.

Stegman, M. A. (1969). Accessibility models and residential location. Journal of the American Institute of Planners, 35, 22-29. https://doi.org/10.1080/01944366908977823

Tipple, G. (2011). Ghana housing profile. Nairobi, Kenya: United Nations Human Settlements Programme (UN-Habitat). Retrieved from https://unhabitat.org/sites/default/files/documents/2019-07/ghana_housing_profile.pdf

Trimbath, S., \& Montoya, J. (2002). Housing affordability in three dimensions: Price, income, and interest rate (Policy Brief No 31). California, USA: Milken Institute. 
Trussell, B. (2010). The bid rent gradient theory in Eugene, Oregon an empirical investigation.

Retrieved

from

http://economics.uoregon.edu/wp

content/uploads/sites/4/2014/07/BenjaminTrussell.pdf

UN - Habitat. (2003). Rental housing-An essential option for the urban poor in developing countries. Retrieved from http:/www.urbancentre.utoronto.ca/ pdfs/library/UNHabitatRentalHousing.pdf

UN Habitat. (n. d.). The right to adequate housing (Fact Sheet No. 21/Rev.1). Retrieved from http://www.ohchr.org/Documents/Publications/FS21_rev_1_Housing_en.pdf

UN-Habitat. (2015). Habitat iii issue papers: 20 - housing. Retrieved from http://unhabitat.org/wp-content/uploads/2015/04/Habitat-III-Issue-Paper-20_Housing-2.0.pdf

UN-Habitat. (2011). Ghana housing profile. Nairobi, Kenya: UNON, Publishing Services Section.

Vakil, A. C. (1999). Problems and prospects of housing CBOs: An analysis of 30 case studies from Africa and Latin America, 1964-1994. Cities, 16(6), 409-422. https://doi.org/10.1016/S0264-2751(99)00039-6

Wong, K. L. (2015). The housing crisis and the third sector. Unpublished Doctor of Philosophy Thesis, University of California.

Yakubu, I., Akaateba, M. A., \& Akanbang, B. A. A. (2014). A study of housing conditions and characteristics in the Tamale Metropolitan Area, Ghana. Habitat International, 44, 394-402. https://doi.org/10.1016/j.habitatint.2014.08.003

Yalley, P. P., \& Ofori-Darko, J. (2012). The effects of Ghana's oil discovery on land and House prices on communities nearest to the oil field in Ghana (Case Study: Kumasi and Sekondi Takoradi). Paper presented at the 4th West Africa Built Environment Research (WABER) Conference, Abuja, Nigeria, 24-26 July 2012.

Yao, C. (2011). Measuring housing affordability in Beijing. Unpublished Master's Thesis.

Yirenkyi, J. N. (2014). Urban housing supply challenges and implications for affordable housing in Accra. Unpublished Master's Thesis, University of Ghana, Ghana.

Zainal, A. H. (2010). House price and affordability in housing in Malaysia. Akademika, 78, $37-46$.

Zohrabi, M. (2013). Mixed method research: Instruments, validity, reliability, and reporting findings. Theory and Practice in Language Studies, 3(2), 254-262.

\section{Copyright Disclaimer}

Copyright for this article is retained by the author(s), with first publication rights granted to the journal.

This is an open-access article distributed under the terms and conditions of the Creative Commons Attribution license (http://creativecommons.org/licenses/by/3.0/). 